\title{
Civil society: any way out from the dead end?
}

\begin{abstract}
This contribution neither reviews civil society's development in former Yugoslavia before, during and after the recent wars (but refers to it in an explicit way), nor delivers a new theory about civil society (in the Balkans); it proposes instead a framework facilitating the discussion of some crucial questions centred on the state-civil society relationship in the context of a war-to-peace transition process. Combining a political economy and anthropological approach, this article aims to explore - against the background of some conceptual clarifications - the current global architecture of the civil society-state nexus. The text focuses on the consequences of the emergence of a neo-liberal governance-beyond-the-state, on new social and political transnational practices and on the necessity to rethink the question of multi-level governance and, thus, of space and scale. The last section examines the tricky question of whether there is a way out of the dead end.
\end{abstract}

Keywords: civil society, civil society-state relations, new practices of governance, globalisation, participatory democracy, social emancipation

The blind leading the blind?

This articles does not review the development of civil society in the former $\mathrm{Yu}$ goslavia in the recent period - though it clearly refers to the recent history - and neither does it deliver a new theory of civil society; instead, it proposes a framework facilitating the discussion of some crucial questions centred on the relationship between state and civil society in the context of a transition process from a time of war to a time of peace.

At first, we may think that almost everything has been said about civil society in the post-Yugoslav sphere. ${ }^{2}$ How could anything new surprise us? We have to pay attention to a new generation of researchers who assert:

There is little that we know about the process through which the imminence of an armed conflict awakened dormant social networks, strengthened existing activist circles and/or created new ones, ${ }^{3}$

1 This article was first presented in the framework of the international conference $\operatorname{War}(s)$ in Yugoslavia - Twenty Years Later organised by the Alps-Adriatic University of Klagenfurt, 1 December 2011.

2 For an overview, see Martina Fischer (2011) 'Civil Society in Conflict Transformation: Strength and Limitations' in Beatrix Austin, Martina Fischer and Hans J. Giessmann (Eds.) Advancing Conflict Transformation Opladen: Barbara Budrich Publishers: 287-313.

3 Bilić, Bojan (2012) 'Contentious Socialists: Recovering the Main Precursors of (Post-)Yugoslav Anti-War Engagement' in Paul Stubbs and Christophe Solioz (Eds.) Towards Open Regionalism in South East Europe Baden-Baden: Nomos, SEIP Vol. 6. 
and who argue, more radically, that civil society as a concept is:

No longer useful as a theoretical device for assisting us to appreciate the complex political and social dynamics of post-Yugoslav societies. ${ }^{4}$

Debates on the theory and practice of democracy may be positioned in new terms, but we may also observe experimentation with different modes of political action focusing on resistance to neo-liberalism, on proactive participatory democracy and on emancipatory initiatives. Also in south-east Europe, new collective actors are emerging - for which

Many of the (...) Yugoslav civic pioneers have become a reactionary mainstream. ${ }^{5}$

Beyond the critical/polemic tone, this tends to indicate that we are at a turning point.

Civil Society Organisations (CSOs) - more specifically, citizenship initiatives aiming at social transformative action, and thus related to the activities of state-building are viewed as forces for change entitled to influence politics and, therefore, as 'strong enough to counter-balance the state' ${ }^{6}$ However, after more than twenty years of civil society activism and NGO development in south-east Europe, strategies for strengthening civil society and social activism have produced mixed results. Thus, we may ask if these civic forces have gained more ground in influencing local and international politics.

During the wars, international and local NGOs were involved in service delivery and in the provision of humanitarian, medical, legal and social aid, while CSOs were focused on human rights monitoring and protection activities. If civil society actors discussed the various conflict resolution scenarios, they were neither involved in the peace processes nor were they given a prominent role in the post-settlement phase. At most they were 'small oases' acting in 'highly limited spheres of public, political and cultural life'. ${ }^{7}$ Last but not least, they remained marginalised and overshadowed by larger international organisations. ${ }^{8}$

As for the post-war period, in spite of the NGO boom and excepting a few success stories, the result is rather disappointing. Standing for many experts, Mark Duffield pinpoints:

4 Bilić, Bojan (2011) 'A Concept that is Everything and Nothing: Why Not to Study (Post-)Yugoslav Anti-War and Pacifist Contention From a Civil Society Perspective' Sociologija 52(3): 300 .

5 ibid.

6 Gellner, Ernest (1994) Conditions of Liberty: Civil Society and Its Rivals London: Hamish Hamilton: 5.

7 Savić, Obrad (2004) 'Concept of Civil Society in Former Yugoslavia' in Dane R. Gordon and David C. Durst (Eds.) Civil Society in Southeast Europe Amsterdam/New York XXIII: 77.

8 See James Lyon (2006) 'Overcoming Ethnic Politics in Bosnia?' in Martina Fischer (Ed.) Peacebuilding and Civil Society in Bosnia-Herzegovina: Ten Years after Dayton Berlin: Lit Verlag, p. 67. 
In practice international intervention has so far produced a largely weak, divided and vulnerable NGO sector. ${ }^{9}$

CSOs have proved to be too weak to create a reform consensus within the various countries of the region and to push the process of state-building. The expectation that civil society would bring about political change, exert pressure and have an impact at political level has not (yet) been fulfilled. ${ }^{10}$ Many local NGOs have passed through an institutionalisation process, formalising and professionalising their structures, but the reconfiguration process for civil society actors has been more problematic. In some countries, institutional lobbying or collaboration with the state has substituted disruptive protest tactics, but the European Union (EU) integration perspective has proved to be a more efficient drive for changes. On their side, 'internationals' have lost interest in the region and moved to other places to reproduce the same. Thomas Carothers sums up:

A boom period follows, but then within a few years the hoped-for dramatic results do not appear and cracks in the edifice start to show. Restless aid providers move on in search of a new romance. ${ }^{11}$

Is civil society in the post-Yugoslav sphere thus at a dead end? If so, why? Because 'civil society' is not relevant in war-torn societies, because it was (partially) imposed, because it is Euro-centric biased...12

In an approach which combines political economy and anthropology, this article aims to explore, against the background of some important conceptual clarifications, which follow, the current global architecture of the civil society-state nexus. The text focuses on the consequences of the emergence of a neo-liberal governance-beyondthe-state, as well as on new social and political transnational practices and on the need to rethink the question of multi-level governance and, thus, of space and scale. Ultimately, the article examines the tricky question of whether there is a way out of the apparent dead end which civil society in the region faces.

\section{Conceptual clarifications}

I will briefly tackle some conceptual issues related to 'civil society': a concept that entered English through the Latin translation of Aristotle's koinonia polizike (societas

9 Duffield, Mark (1996) Social Reconstruction in Croatia and Bosnia: An Exploratory Report for SIDA Birmingham: Centre for Regional and Urban Studies.

10 See Fischer (2011) op. cit: 302.

11 Carothers, Thomas (2004) Critical Mission: Essays on Democracy Promotion Washington, DC: Carnegie Endowment for International Peace: 7.

12 If we might question the significance of an essentially western-coined concept for societies with their own cultural and political logics, it would be wrong to disregard intellectuals in India and Latin America, in the Middle East and in China, in Africa and south-east Europe, who infused in the late 1980s new life into the category. See Sunil Khilnani (2001) 'The development of civil society' in Sudipta Kaviraj and Sunil Khilnani (Eds.) Civil Society: History and Possibilities Cambridge: Cambridge University Press, p. 12. 
civiles), was then extensively used by Locke and Hegel ${ }^{13}$ and gained popularity only in the late 1960s, linked to the mushrooming of social movements, ${ }^{14}$ the recovery of Antonio Gramsci and his adoption by intellectuals opposing authoritarian regimes in Eastern Europe - notably in Poland.$^{15}$ Following Gramsci, the Italian Marxist writing in the 1930s, civil society is commonly viewed as one of the three components that define the content and structure of society (the others being the state and the market). ${ }^{16}$ Accordingly, civil society is the sum total of private actors (outside the state and the market) and constitutes the terrain of social struggle for hegemony: CSOs were thus used by the leading class to impose its power or, alternatively, as a potential instrument of emancipation and counter-hegemony by opposing actors. ${ }^{17}$

Further, civil society is a public sphere - which mediates between society and state - characterised by public accountability and the rule of law. ${ }^{18}$ This aspect is particularly relevant insofar as it enables us to distinguish civil society from NGOs and informal networks. Thomas Carothers points out:

It is a mistake to equate civil society with NGOs. Properly understood, civil society is a broader concept, encompassing all the organizations and associations that exist outside of the state and the market. ${ }^{19}$

In other words, the (high) number of NGOs that have emerged in the Balkans is certainly not a guarantee of the further development of civil society - especially if NGOs are the dominant component, overshadowing an absence of citizen action groups, an independent media and a critical public sphere.

In order to overcome the misunderstandings related to the concept of 'civil society' and to map different types of civil societies, we may use Jan Kubik's effective taxonomy, focusing on four attributes: 'secondariness';20 transparency; tolerance; and legality:

13 Khilnani emphasises that Hegel's question concerned the possibility of creating and sustaining a community under modern conditions; in response to this problem, he introduced the distinction between 'state' and 'civil society'. Khilnani (2001) op . cit: 17-24.

14 See the empiric field studies conducted by Alain Touraine, Michel Wieviorka and François Dubet in the late 1970s and 1908s; the approach and methodology was exposed in Alain Touraine (1978) La voix et le regard Paris: Seuil.

15 See Alain Touraine, Michel Wieviorka, François Dubet and Jan Strzelecki (1982) Solidarité Paris: Fayard.

16 See Antonio Gramsci (1971) Selections from the Prison Notebooks London: Lawrence and Wishart.

17 See Jean L. Cohen and Andrew Arato (1992) Civil Society and Political Theory Cambridge: MIT Press, p. 149.

18 See Jürgen Habermas (1992) 'Further Reflections on the Public Sphere' in Craig Calhoun (Ed.) Habermas and the Public Sphere Cambridge: MIT Press, pp, 289-339.

19 Carothers (2004) op. cit: 100.

20 Insofar as civil society is composed of secondary groups. 
Table 1 - Legal transparent civil society and imperfect civil societies

\begin{tabular}{|l|l|l|l|l|}
\hline & \multirow{2}{*}{$\begin{array}{l}\text { Non-transparent } \\
\text { unofficial public } \\
\text { domain }\end{array}$} & Illegal & $\begin{array}{l}\text { Selectively } \\
\text { legalised }\end{array}$ & $\begin{array}{l}\text { Legally protected } \\
\text { rule of law }\end{array}$ \\
\cline { 3 - 5 } & $\begin{array}{l}\text { Clientelist } \\
\text { networks } \\
\text { autocratic, } \\
\text { often intolerant }\end{array}$ & $\begin{array}{l}\text { Illegal religious } \\
\text { cults; } \\
\text { illegal } \\
\text { paramilitary } \\
\text { organisations }\end{array}$ & $\begin{array}{l}\text { Officially } \\
\text { authorised } \\
\text { religious cults }\end{array}$ & $\begin{array}{l}\text { Legalised } \\
\text { paramilitary } \\
\text { clubs }\end{array}$ \\
\hline $\begin{array}{l}\text { Horizontal } \\
\text { democratic } \\
\text { (usually) } \\
\text { tolerant }\end{array}$ & $\begin{array}{l}\text { Democratic } \\
\text { underground } \\
\text { dissident / } \\
\text { oppositional } \\
\text { organisations }\end{array}$ & $\begin{array}{l}\text { ITCS } \\
\text { 'democratic' } \\
\text { dissident groups }\end{array}$ & $\begin{array}{l}\text { TCS } \\
\text { officially } \\
\text { authorised } \\
\text { associations }\end{array}$ & $\begin{array}{l}\text { LTCS } \\
\text { 'classic' civil } \\
\text { society }\end{array}$ \\
\hline
\end{tabular}

Legend: ITCS: Illegal Transparent Civil Society; TCS: Transparent Civil Society; LTCS: Legal Transparent Civil Society.

Source: Jan Kubik The State and civil society. Traditions and news forms of governing p. 37.

Away from a normative and ideal-type concept, I suggest a more inclusive approach from which to view civil society more pragmatically, encompassing a diversity of spaces, actors and institutional forms - including, therefore, interest groups, formal organisations (trade unions, professional NGOs and research institutes), informal networks, advocacy groups (such as human rights organisations), grassroots and massbased social movements and also traditional and community-based organisations. ${ }^{21}$ The value of these networks is, as evidenced by Robert Putnam, to increase inter-connectedness and to foster robust reciprocity and trust because they cut across social cleavages; therefore, they contribute considerably to bridging social capital and common meanings. ${ }^{22}$

Of course, civil society has to be understood on its own terms in complex Yugoslav society. In the 1980s and 1990s, especially in rural areas, kinship- and communitybased networks were the most influential: hierarchically-ordered organisations (such as the army, churches, mafias and other parallel networks) became privileged to the detriment of horizontally-structured organisations (such as sports clubs, mutual aid societies, cultural associations and voluntary unions).

21 International organisations have largely underestimated the influence of such actors (e.g. the mesma zajednica and neighbourhood associations) - the political sensitiveness of projects, as well as the structural legacies and social capital of the pre-war past, were very often not taken into account. See Fischer (2011) op. cit: 301-2; and Paul Stubbs Paul (2001) 'Social Sector or Diminution of Social Policy?’ in Žarko Papić (Ed.) International Support Policies to South Eastern European Countries: Lessons (Not) Learnt from BiH Sarajevo: Open Society Institute, pp. 57-107.

22 See Robert D. Putnam (2003) Making Democracy Work: Civic Traditions in Modern Italy Princeton: Princeton University Press, pp. 173-4. 
Zagorka Golubović, who conducted empirical studies in Serbia in the 1990s, explains why this happened. According to her, the belated civil society of Serbia is the result of complex internal sociological and anthropological factors contributing to the formation of an authoritarian mentality. Thus, a failed transition process alone does not explain why civil society development was arrested in the former Yugoslavia. Golubović considers the residues of a traditionalist society and patriarchal relationships to be the main factors that hindered the emergence of civil society organisations. This would also explain why, with the fall of the communist system, Yugoslavia found itself in a more problematic situation than other east European countries, as well as why CSOs developed less intensely in post-communist Yugoslav society than under authoritarian communism.

Results of socio-anthropological and psychological research conducted in Serbia in the early 1990 s do indeed indicate a high correlation linking nationalism, authoritarianism and traditionalism as the bases for an authoritarian social character. ${ }^{23}$ Not only did traditionalism and authoritarian communism merge in the period between 1945 and 1990 but, in the context of the awakening of nationalist ideology and the strategy of the formation of nation states at the end of the 1980s, a process of re-traditionalisation limited modernisation in the former Yugoslavia and blocked - more than just through censorship - the emergence of a free and critical public opinion. Thus:

The authoritarian personality as the desirable social character and the dominant basic personality type in Serbia gave rise to social behaviour little in accordance with the necessary processes of the democratic transformation of society. ${ }^{24}$

Against this background, we may understand the strategy of authoritarian regimes as a project aiming to build a 'community' without a civil society. ${ }^{25}$

This explains why various forms of pre-war civic activity and interest-based associations - which were more developed in Ljubljana and Zagreb than in Sarajevo and Pristina - did not gain traction in the late 1980s. Nevertheless, oases of reform-oriented civil society and critical public opinion existed as elements from the protest movement during the 1960 s and as intellectual groups resisting the revival of authoritarianism. ${ }^{26}$

23 See Zagorka Golubović, Bora Kuzmanović and Mirjana Mašović (1995) Društveni karakter I društvene promene u svetlu nacionalni sukoba [Social Character and Social Change in the Light of National Conflicts] Belgrade: Filip Višnji.

24 Golubović, Zagorka (2004) 'Traditionalism and Authoritarianism as Obstacles' in Dane R. Gordon and David C. Durst (Eds.) Civil Society in Southeast Europe Amsterdam/New York XXIII: 93.

25 See Gagnon, Jr, V. P. (2004) The Myth of Ethnic War: Serbia and Croatia in the 1990s Ithaca: Cornell University Press; and Vukašin Pavlović (Ed.) (1995) Potisnuto civilno društvo [Suppressed Civil Society] Belgrade: EKO Centor.

26 For an overview on civil society in Yugoslavia from the 1960s onwards, see Jasna Adler (2001) 'La société civile et la fin du communisme' Transitions (2): 111-30; on the 1968 student movement in Yugoslavia and feminist engagement, see Bilić (2012) op. cit. Specifically on the Praxis group, see Ursula Rütten (1993) Am Ende der Philosophie? Das gescheiterte „Modell Jugoslawien“ Klagenfurt: Drava. 
The way in which CSOs relate to the state-level is context-dependent also in a broader sense. First, the state-civil society relationship may be differently structured according to various regime types. Following Linz and Stepan's distinction between five regime types (democratic, authoritarian, totalitarian, post-totalitarian and sultanistic), ${ }^{27}$ Kubik considers the role of CSOs in relation to the four core capacities of the state. ${ }^{28}$ Table 2 shows the role of CSOs as regards two regime types.

Complementarily, Gordon White emphasises that civil society forces may choose between three key strategies: accept the political status quo (e.g. be supportive of authoritarian rule); foster a liberal democratic polity; or work towards radical changes. ${ }^{29}$ Catherine Barnes further details CSOs' positioning that characterises their relations with governments as alternatively complicit, contractual, contributing, complementary or contesting/confronting. ${ }^{30}$

\section{Table 2 - Regime types}

\begin{tabular}{|l|l|l|}
\hline \multirow{2}{*}{ Type of capacity } & \multicolumn{2}{|c|}{ Regime type } \\
\cline { 2 - 3 } & \multicolumn{1}{|c|}{ Authoritarian } & \multicolumn{1}{c|}{ Democratic } \\
\hline $\begin{array}{l}\text { Bureaucratic/administrative } \\
\text { capacity }\end{array}$ & $\begin{array}{l}\text { CS as weak agent of } \\
\text { accountability }\end{array}$ & $\begin{array}{l}\text { CS as quality controller and } \\
\text { agenda setter }\end{array}$ \\
\hline Coercive capacity & $\begin{array}{l}\text { CS as sporadic civil rights } \\
\text { defender }\end{array}$ & $\begin{array}{l}\text { CS as political and civil rights } \\
\text { monitor }\end{array}$ \\
\hline Economic/financial capacity & CS as monitor of fiscal fairness \\
\hline Regularising capacity & $\begin{array}{l}\text { CS as producer of } \\
\text { emancipatory visions }\end{array}$ & $\begin{array}{l}\text { CS as cultural/ideological } \\
\text { pluraliser }\end{array}$ \\
\hline
\end{tabular}

Source: Kubik (2007) op. cit: 45.

Second, the wider political-economic transformations must be acknowledged. Swyngedouw captures it thus:

The position and role of civil society are closely related to the dynamics of other 'moments' of society - i.e. state and economy. ${ }^{31}$

27 See Juan Linz and Alfred Stepan (1996), Problems of Democratic Transition and Consolidation: Southern Europe, South America and Post-Communist Europe Baltimore: Johns Hopkins University Press.

28 Kubik, Jan (2007) 'The State and civil society. Traditions and news forms of governing' in Emil Brix, Jürgen Nautz, Rita Trattnigg and Werner Wutscher (Eds.) State and Civil Society Vienna: Passagen, p. 44.

29 See Gordon White (1994) 'Civil Society, Democratisation and Development (I): Clearing the Analytical Ground' Democratization 1(2): 375-90.

30 See Catherine Barnes (2006) Agents for Change. Civil Society Roles in Preventing War and Building Peace Den Haag: European Centre for Conflict Prevention: 99.

31 Swyngedouw, Erik (2005) 'Governance innovation and the citizen: The Janus face of governance-beyond-the-state’ Urban Studies 42(11): 1996. 
Globalisation, the increasingly transnational political economy, new practices of governance and the post-war neo-liberal context - characterised notably by the reduction in the welfare national state, by the state losing its powers of regulation and by the emergence of networked-based forms of governance and, accordingly, of new actors (e.g. NGOs, think tanks, lobbies) - are heavily influencing the new architecture of the civil society-state relationship.

Civil society's Janus face

Ongoing state-building/consolidating in the Balkans must distract attention from this region also being affected by the twin processes which may be observed almost everywhere: 'down-scaling' and 'up-scaling'.

The former combines decentralisation and privatisation: the services and operations of government - emphasising the principle of subsidiarity and the privatisation of services - are transferred or 'outsourced' to non-state entities. This is a trend followed by donor governments that have increasingly outsourced the implementation of aid programmes. ${ }^{32}$ Consequently, non-state actors - mostly market-based and oriented - have become increasingly tasked with the social, economic and cultural activities previously assumed by the state. In this context, NGOs have been assigned new service functions, especially in the social and health sectors. Consequently, some NGOs have turned into GONGOs (government-organised NGOs - or (N)GOs) working as much from 'below' than from 'above'. Ferguson and Gupta view the partial 'delegation' of the state's functions as:

A key figure, not only of the operation of a national state, but of an emerging system of transnational governmentality. ${ }^{33}$

The context-related specificity amplifies this aspect in the Balkans where the intrusiveness of external actors - in prioritising economic liberalisation and fast privatisation - have considerably enhanced this process as well as that of its alter ego, 'upscaling'.

The latter refers to the transfer of policy responsibility to sub-national or transnational forms of governance. This shift has developed specific contours for particularly fragile states in the Balkans (e.g. Bosnia and Herzegovina, and Kosovo): key aspects of state policy and economic governance are (in)directly formulated - often 'presented' (or imposed) as adjustments - in places like Brussels, London, New York, Washing-

32 See Tobias Debiel and Monika Sticht (2005) Towards a New Profile? Development, Humanitarian and Conflict Resolution NGOs in the Age of Globalisation Duisburg-Essen: Institute for Development and Peace, INEF Report No. 79.

33 Ferguson, James and Akhil Gupta (2002) 'Spatializing states: toward an ethnography of neoliberal governmentality' American Ethnologist 29(4): 990. The author borrows and extends the concept of 'governmentality' from Michel Foucault who drew attention to all the processes by which the conduct of a population is governed. See Michel Foucault (2001) 'La "gouvernementalité" Dits et écrits II, 1976-1988 Paris, Gallimard: 633-57 and Michel Foucault (2004) Sécurité, territoire, population. Cours au Colège de France (1977-78) Paris: Gallimard/Seuil. 
ton... and Den Haag. This scalar re-organisation of the state results in the 'emergence of a neo-liberal governance-beyond-the-state' and redefines in fundamental ways the relationship between state and civil society. ${ }^{34}$ This is well perceived by CSOs - and by organised transnational criminal networks - acting both locally and globally at one and the same time, and moving whenever necessary directly beyond state borders at transnational level. We are thus in the presence of actors that are not any longer 'below' the state but part of a transnational sphere that co-exists (compromises, contests and/ or colludes) with the nation-state system. ${ }^{35}$

Paul Stubbs, in analysing - beyond the classical and misleading metaphors of "verticality' and 'encompassment' 36 - how multi-level governance is also present in southeast Europe, highlights the necessity to think multi-level governance out of the box and towards:

A more nuanced, if at times seemingly unsystematic and intuitive, search for the lived encounters of agents, concepts, forms of governance, and modes of policy transfer. Such an approach must move between macro-, meso- and micro-levels, and confront meta-level questions of memories, value systems, capacities and forms of trust and mistrust. ${ }^{37}$

Meanwhile, politics in the post-Yugoslav sphere continue to rely on a vertically encompassing state paradigm and are unable, or unwilling, to capture political and economic practices that cannot be understood with the 'nation-state' lens. Beyond outdated metaphors and approaches, a new landscape is emerging that:

Can be understood only through a rethinking of questions of space and scale. ${ }^{38}$

These new institutional 'fixes' have thus begun to challenge traditional state-centred forms of policy-making and have generated new forms of 'governance-beyondthe-state'. Swyngedouw criticises the assumptions that governance inherently signifies new democratic arenas of citizenship participation: using the Foucaldian notion of 'governmentality', he argues that, with new forms of policy-making 'beyond the state', political citizenship is being redefined to empower new groups (e.g. policy advocates and think tanks) and to disenfranchise those that do not conform to the new marketoriented 'rules of the game'. These new strategies (focusing on performance) to empower citizens are an integral part of:

34 Swyngedouw (2005) op. cit: 1998.

35 See, against the background of an African case study, Ferguson and Gupta (2002) op. cit: 993-4.

36 See Ferguson and Gupta (2002) op. cit: 982: 'These two metaphors work together to produce a taken-for-granted spatial and scalar image of a state that both sits above and contains its localities, regions and communities.' The authors' intention is not to denounce a false ideology, but 'to draw attention to the social and imaginative processes through which the state is made effective and authoritative.'.

37 Stubbs, Paul (2002) 'Stretching Concepts Too Far? Multi-level Governance, Policy Transfer and the Politics of Scale in South East Europe' South European Politics 25(4): 76.

38 Ferguson and Gupta (2002) op. cit: 990. 
The consolidation of an imposed and authoritarian neo-liberalism, celebrating the virtues of self-managed risk, prudence and self-responsibility. ${ }^{39}$

Nevertheless, this does not mean that the state is disappearing - neither 'the end of politics' nor the 'political exclusion' as argued by Noreena Hertz. ${ }^{40}$ The state's sovereignty and capacities are not diminished, they are just shifting: being displaced from formal to (in)formal techniques of governance. Instead, we may speak of a partial 'destatisation' ${ }^{41}$ that empowers civil society and the new elites to take benefit from as compared to the 'transparent' democratic rules and codes - the often opaque networks, institutional arrangements and lineages of representation; not to mention the lack of explicit mechanisms of accountability and legitimacy. Thus - and contrary to what the conventional state-civil society dichotomy suggests - the boundaries between both are blurred and the two spheres overlap. ${ }^{42}$

Moreover, civil society organisations tend to be - as highlighted above - incorporated into the system, a shift that prevents them assuming a more critical political role. This is even more evident in south-east Europe as this re-orientation has been enhanced by the shift from typical wartime to post-war roles and functions. In the war-to-peace transition contex ${ }^{43}$ that currently characterises the post-Yugoslav sphere, most civil society actors have established professionalised structures, while some have integrated with the political sphere and others have joined the private sector. And, for most of them, institutional lobbying or collaboration with the state (in the fields of service delivery and policy-making) are replacing disruptive protest tactics. Due to the global context as the specific war-to-peace transition process, CSOs aiming at social transformative action are looking as Janus in two opposite directions: on the one side towards contractual/contributing strategies; and, on the other, towards contesting/confronting ones.

Any way out from the dead end?

Swyngedouw highlights that:

Non-normative and socially innovative models of governance as non-hierarchical, networked and (selectively) inclusive forms of governmentality cannot be sustained uncritically. ${ }^{44}$

39 Swyngedouw (2005) op. cit: 1998.

40 See Noreena Hertz (2002) The Silent Takeover: Global Capitalism and the Death of Democracy London: Arrow, pp. 88-108. Contrary to what the title suggests, the author repeatedly avoids one-sided views.

41 See Bob Jessop (2002) The Future of the Capitalist State Oxford: Blackwell. Nevertheless, it must be noticed the state has not lost much of its significance.

42 See White (1994) op. cit.

43 See Veronique Dudouet (2007) Surviving the Peace. Challenges of War-to-Peace Transitions for Civil Society Organisations Berlin: Berghof Research Centre for Constructive Conflict Management, Berghof Report No. 16.

Swyngedouw (2005) op. cit: 2002. 
Here, we have to question whether the option to 'opt out', following the motto 'shop and protest rather than vote' - thus using strategies ranging from boycott (consumer movements) to protest movements ${ }^{45}$ - contributes to the actual placing of alternative policies on the agenda; are they not just a symptom of political (self) exclusion? Observations repeatedly made in the Balkans, notably in Bosnia and Herzegovina (e.g. Dosta!) and in Kosovo (e.g. Vetëvendosje), illustrate the limits of strategies confined to protest-although Otpor! in Serbia certainly exemplifies a successful initiative. NGO 'projectomania' and marginalised pockets of activism have turned out to be unable to 'bridge the gap' and - beyond producing new meanings, discourses and practices forge ahead with a political consensus around alternative policies.

Additionally, Hertz acknowledges that neither consumer and shareholder activism nor protest movements are long-term solutions, since they leave politics outside of the arena. CSOs - while facing the above-mentioned contradictory aspects of new forms of governance - have to restore citizens' confidence and their identification with the polity, and bridge the gap between democracy and social participation. Instead of 'stepping outside', critical constructive strategies have to 'democratise democracy' 46 and thus - opposing 'low-intensity democracy' 47 - reload the public sphere and democratic institutions by exploring different modes of participatory democracy and new political practices. CSOs have here - precisely in semi-peripheral countries and fragmented and war-torn ones - a decisive role to play. Accordingly, Hertz presents some concrete suggestions, such as the establishment of an independent international commission investigating the impact of economic globalisation and of a World Social Organisation as a counterweight to the World Trade Organisation. ${ }^{48}$

As for the Balkans, the establishment of an inclusive economic and social committee would certainly be a move in the right direction. However, these forums do not resolve the problem of non-representational forms of autocratic elite technocracy. Associative projects in local development, alternative forms of access to credit, transnational networks of solidaristic economic activity and citizen initiatives in environmental impact assessment and regional planning - all these stand for various forms of critical engagement and illustrate that other futures are possible.

The increasingly complex multilayered (multi-level, multi-scalar and hybrid-like) governance configuration increases people's scepticism about government and politics and creates a more problematic relationship between the state and civil society. In many parts of the world, what feeds people, organises them and constructs their worldview

45 See Hertz (2002) op. cit: 194-211.

46 A concept coined by Boaventura de Sousa Santos. See Boaventura de Sousa Santos (2008) (Ed.) Democratizing Democracy: Beyond the Liberal Democratic Canon London: Verso and Balibar; Etienne (2010) La Proposition de l'égaliberté Paris: PUF, p. 8.

47 de Sousa Santos, Boaventura (2002) Toward a New Legal Common Sense London: Butterworths, p. 293.

48 See Noreena Hertz (2001) 'A Plan for the World' New Statesman 22 October; available at www.newstatesman.com/200110220017 [accessed 18 November 2011]. 
is not the state and its formal manifestations (at local, national or regional levels), ${ }^{49} \mathrm{but}$ the informal sector and its multitude of networks, civil societies and associations again, at different levels (linking the national, sub-national and extra-national spheres). Of course, people participate not solely in the formal or the informal sector; rather, they move in and out of both and it is precisely these kinds of interactions, and the various scales to which they simultaneously refer, which should be captured.$^{50}$ Janet Newman points out:

[The] dispersal of state power opens up new ways in which citizens can engage in the politics of localities and regions and participate in 'project politics' on specific issues. ${ }^{51}$

Accordingly, CSOs have, first, to reconnect with traditional relationships, social capital and institutions in order to avoid the harm done by conventional exported statebuilding approaches; ${ }^{52}$ and, second, to articulate the needs of their domestic constituencies with wider geographical scales who are facing the complex multilevel and multiscalar dimensions of transnationalisation and globalisation. At first glance, proactive engagement - praxis - is needed here: CSOs in south-east Europe, as well as right across the post-communist area, seem to be rather poorly networked in terms of transnational actions; ${ }^{53}$ they could only benefit from transnational networks of participatory democracy initiatives which are actively engaged in the shift from a 'low-intensity democracy' to a 'high intensity' one. ${ }^{54}$

CSOs have thus to get more deeply involved simultaneously on the horizontal and on the vertical levels; they have to move more resolutely beyond national spheres and address actual challenges through new social and political practices, articulating both the global and the local. Civil society, in the Balkans as well as elsewhere, is a promising laboratory for the reinvention of participatory democracy and social emancipation. ${ }^{55}$

49 See Christophe Solioz and Paul Stubbs (2009) 'Emergent Regional Co-operation in South East Europe: Towards 'Open Regionalism'?' Journal of SEE and Black Sea Studies 9(1): $1-16$.

50 See Morten Bøås, Marianne H. Marchand and Timothy M. Shaw (2003) 'The Weave-World: The Regional Interweaving of Economies, Ideas and Identities' in Fredrik So $\square$ derbaum and Timothy M. Shaw (Eds.) Theories of New Regionalism: A Palgrave Reader Basingstoke: Palgrave, p. 204.

51 Newman, Janet (2005) Remaking Governance: Peoples, Politics and the Public Sphere Bristol: Policy Press, p. 4.

52 See Volker Boerge (2011) 'Potential and Limits of Traditional Approaches in Peacebuilding' in Beatrix Austin, Martina Fischer and Hans J. Giessmann (Eds.) Advancing Conflict Transformation Opladen: Barbara Budrich Publishers, pp. 431-454.

53 See Marc Howard (2003) The Weakness of Civil Society in Post-Communist Europe Cambridge: Cambridge University Press.

54 See the collection of reports from the global south - India, South Africa, Mozambique, Colombia, and Brazil - published in the volume edited by de Sousa Santos (2010) op. cit; and the other volumes related to the Reinventing Social Emancipation project (information is available at: www.ces.fe.uc.pt/emancipa) [accessed 18 November 2011].

55 This text reflects my own thoughts, but their development has benefited from an ongoing fruitful discussion - taking place over several years - with Paul Stubbs. 